Валентина Питулић

Филозофски факултет

Универзитет у Приштини

Са привременим седиштем

у Косовској Митровици

valentina.pitulic@pr.ac.rs

https://doi.org/10.18485/ai_diskurs_pobede.2019.ch2

821.163.41.09-13:398

\title{
ПОБЕДНИЦИ СТАРЦА МИЛИЈЕ
}

У раду ћемо се бавити ликовима једног од најбољих певача Вука Караџића, Старца Милије. Вуку Стефановићу Караџићу Старац Милија казивао је четири песме у којима долази до одступања од устаљених формула епског певања. У раду ћемо показати на који начин је овај даровити певач померао границе епског певања и одступао од формула у оквирима којих су се кретали епски ликови. Посебну пажњу обратићемо на лик Бановић Страхиње, стариша дервиша, Латинку девојку и Иву Црнојевића, јер се на поступцима ових ликова најбоље уочава специфичност певања Старца Милије где је линија између победника и пораженог веома танка.

Кључне речи: старац Милија, победник, епски јунак, етика, самоћа, пораз.

Старац Милија је један од најбољих Вукових певача. Говорећи о индивидуалним одликама његовог певања у

1 Рад је рађен у оквиру пројекта Срйско усмено сйваралашйво у интеиеркулитурном коgу (бр. 178011) Института за књижевност и уметност Београд, који финансира Министарство просвете, науке и технолошког развоја Србије. 
књизи Вукови ӣeвачи ${ }^{2}$ Владан Недић наводи да је особеност певања овог певача скренула пажњу многим истраживачима српског усменог наслеђа међу којим су: Веселин Чајкановић ${ }^{3}$, Иван Димитријевић ${ }^{4}$, Богдан Поповић ${ }^{5}$, Хенрик Барић ${ }^{6}$, Петар Бакотић ${ }^{7}$ и други. У новијим истраживањима особитости певања Старца Милије истраживачи су отишли и корак даље, тумачећи његову поетику из различитих углова. Навешћемо само неке, који се делом односе и на проблем који ће бити тема анализе у овом раду: Радослав Меденица ${ }^{8}$, Јован Деретић ${ }^{9}$, Никола Кољевић ${ }^{10}$, Ненад Љубинковић ${ }^{11}$, Бошко Сувајџић ${ }^{12}$ и други. У својој књизи Вукови йевачи Владан Недић каже да је Старац Милија углавном мењао песме које је затекао, „улазећи у психологију

2 Владан Недић, Вукови иеевачи, Београд, Рад, 1990.

3 Жениgба Максима Црнојевића, српска народна песма с коментаром (В. Чајк), Бизерта, 1917. - Пейнаести срйских нароgних иесама, уредио др Веселин Чајкановић. Београд, 1925.

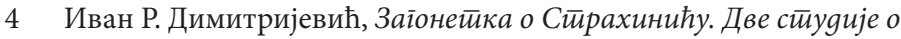
народној књижевности и, Београд, 1930

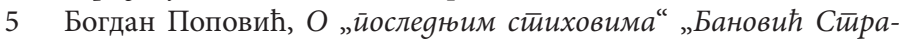
хиња“, Прилози проучавању народне поезије, 1936, год. III, св. 1.

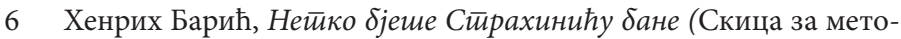
долошку студију), Српски књижевни гласник, 1936, н. С., XLIX.

7 Petar Bakotić Starac Milija, „Skolski vjesnik“, 1962, br. 1, str. 13-25; br. 2, str. 1-23; br. 4, str. 1-11; br. 5-6, str. 23-31, br. 7. Str. 9-19; br. 8, str. 15-32.

8 Radoslav Medenica, Banović Strahinja u krugu varijanata i tema o neveri žene u narodnoj epici, Naučno delo, Beograd, 1965.

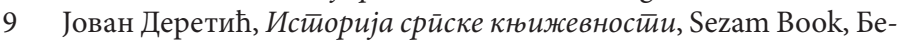
оград, 2013.

10 Никола Кољевић, Иконобории и иконобранитеель, Нолит, Београд, 1978.

11 Ненад Љубинковић, Траїаға и оgіовори, Студије из народне књижевности и фолклора I, Институт за књижевност и уметност, 2010,

12 Бошко Сувајџић, Јунаци и маске, Друштво за српски језик и књижевност, Београд, 2005. 
својих личности“ (Недић 1990: 89), стварајући пре свега ликове Динараца виолентног типа. За јунаке песми „Женидба Максима Црнојевића“ Јован Цвијић наводи да су то плаховити људи који „набујавши, јуре као стреле, изваљујући стене и дрвеће, засипајући шљунком и сипаром плодне њиве и остављајући за собом само разор и пустош“"13. У раду ћемо тражити опозитне моменте у понашању актера догађаја који из сфере поражених прелазе на другу страну, страну победника. Инспиративна је била књига Ненада Љубинковића Траїаға и ogiовори где је аутор на занимљив начин ушао у проблем губитника јунака Старца Милије. Он је подробно вршио анализу све четири песме Старца Милије, говорећи појединачно о ликовима који су у оквиру личних и колективних усуда доживљавали, пре свега људске поразе. Бавећи се психологијом Старца Милије Ненад Љубинковић каже: „Онемоћали, израњављени и посве разочарани Старац Милија јесте песник опседнут испитивањем наличја јунаштва, наличја јунака“ (Љубинковић 2010: 378). Кренућемо трагом наличја онога што на први поглед представља пораженог јунака.

Старац Милија је био необичан певач. ${ }^{14}$ Познато је да је Вук Стефановић Караџић од њега 1822. године, у Крагујевцу, забележио четири песме: „Бановић Страхиња“, „Женидба Максима Црнијевића“, „Сестра Леке капетана“ и „Гавран харамбаша и Лимо“. Ненад Љубинковић, у подробној анализи о губитницима Старца Милије, наводи да „ако се четири Милијине песме посматрају и тумаче као својеврсна обликована и довршена целина - може се говорити о одликама Милијине поетике“ (Љубинковић 2010: 458). Томо Маретић је открио специфичност певања Старца Милије и највећи степен одступања од других певача у начину певања,

13 Јован Цвијић, Говори и чланци, I, Београд, 1921, стр. 240.

14 Владан Недић, Вукови иеевачи, Београд, Рад, 1990. 
али и у самој метрици (Маретић 1907: 142). Поступак Бановић Страхиње, који својој љуби поклања живот, изазвао је у европским научним круговима у 19. веку велику дилему о разлозима овакве одлуке. Вајмарски војвода Карл Августа и Волфганг Гете ${ }^{15}$ били су збуњени овим поступком, тако да је сам Гете протумачио овај чин као „самовољу једног варварина“.

Како је старац Милија јединствен по психолошком понирању у своје ликове поставља се питање шта је то што их чини посебним и другачијим. Не би требало губити из вида сагледавање јунака по антрополошком кључу, по којем је јунак, како наводи Миодраг Павловић онај ко је „ишао до краја, пошто је погинуо, стварно пристао да се жртвује, а не само да победи, што, нормално, хоће сваки човек“ (Павловић 2000: 123). Пратећи губитнике старца Милије о којима пише Ненад Љубинковић, он полази од профила самог певача, посве разочараног, који се бавио наличјем живота и наличјем својих ликова, кога опчињавају „личне драме (оне које се догађају у сенци крупних историјских превирања и које јесу обично њима узроковане), и како оне, када се догоде, мењају читав јунаков живот, јунаков свет“ (Љубинковић 2010: 378). Иако се у песмама Старца Милије оцртава и деструктивна страна јуначког принципа ми ћемо се бавити оним слојем његовог певања у којем победници нису они од којих очекујемо, већ губитници који у конкретним околностима постају тихи победници. У даљој анализи имаћемо у виду њихову невидљиву борбу, која је највећа вредност јунака, а која их ставља на пиједестал узвишених вредности.

15 Види: Милан Ћурчин, Срйска нароgна иесма у немачкој књижевности и превео Бранимир Живојиновић, Народна библиотека Србије - Народна библиотека „Вељко Влаховић“, Београд - Панчево 1987, 148. 
У овом раду фокусираћемо се на тихе победнике у две песме, „Бановић Страхиња“ и „Женидба Максима Црнојевића“, јер је у њима најизразитији опозитни однос јунак/антијунак. Постоји неколико момената у радњама делајућих лица које ће на известан начин окренути на другу страну од очекиваног и изокренути већ устаљену формулу народног казивања. Поћи ћемо од две личности за које у народној традицији већ постоји конотација и одређење хтонског. Као што су у народној традицији представници хтонског аждаја, вештица, дивови, змајеви, баба, у историјском контексту то су Турци, Арапи, Латини који на фону народне традиције, по правилима епске формуле, буду савладани. У поетици Старца Милије доћи ће до формулативног обрта. Он је изашао из традиционалне визуре победника и побеђеног и потпуно изокренуо ствар.

Наиме, Старац Милија је градио своје ликове по етичкој димензији њихових поступака. Он је, као ниједан Вуков певач, улазио у противнички табор и у њему тражио Човека који ће се издвојити из позиције очекиваног. Југовићи и Југ Богдан у песми „Бановић Страхињ“" неочекивано падају и од устаљене формуле јунака постају антијунаци. Изречени ставови Бановић Страхиње и Југ Богдана представљају, како би рекао Бошко Сувајџић „сукоб два јасно одвојена света, два неспојива етичка универзума“ (Сувајџић 2005: 33). Старац Милија прави оквир њиховог пада, као што прави и оквир раста и људског тријумфа Бановић Страхиње. Став Југ Богдана о својој отетој ћерки није одмакао од устаљене формуле:

Ал' ако је једну ноћ ноћила, Једну ноћцу шњиме под чадором, Не може ти више мила бити.

(Вук II 1969: 197) 
Југ Богдан не улази у то да је она отета, да је без своје воље у шатору Влах-Алије. Он не отвара простор могућности њеног отпора, или немогућности да било шта учини. Он заступа устаљено мишљење да нема повратка за жену која је јеgну ноћ ноћила са другим човеком, без претпоставке о било каквом отпору под турским чадором. Југовићи неприкосновено слушају свога оца, али један моменат, који је Старац Милија увео у песму, даје могућност тренутног стида када Југовићи, при одлуци Југ Богдана да их не да у Косово гледају $y$ землииу ирну. У землииу ирну погледаће и некакав млаgu Немағић који поступа као и Југовићи. Њихов јуначки ореол који ће имати у косовским песмама претвара се у морални пад и они губе етичку вертикалу која их је чинила јунацима. Разлог оваквог поступка Ненад Љубинковић види у томе што је Старац Милија изблиза гледао дешавања у Првом и Другом српском устанку, што је видео и лице и наличје победе и победника и гледао на човека оком искуства и духовног понирања у поступке појединаца (Љубинковић 2010: 373-378).

У песми „Женидба Максима Црнојевића“, не очекујемо, по правилима епског певања, да Црнојевићи, попут Југовића, постану другачији од онога што епска формула захтева од њих, а то је да буду јунаци у свакоме смислу. Иво Црнојевић својим поступцима излази из етичке категорије устаљеног поретка. Он на далеко запроси девојку милу шћериу gужgа оg Млетиака (Вук II 1969: 373) и тиме улази у простор опасности коју са собом носи туђа територија и синтагма ирреко мора сиға. Старац Милија, наизглед неважним дијалозима, позиционира пад јунака. То ће се у овој песми догодити у тренутку када, после болести свога сина, пита љубу шта да чине јер треба поћи сватовима по девојку. То је тренутак када певач на сцену изводи оне који су били 
у сенци и који нису имали могућност да искажу своју личност. То су они моменти када долази до изненадних, малих тријумфа ликова из сенке који на тренутак долазе до својих малих победа. Иво Црнојевић пита своју љубу за мишљење тек када је у невољи, да би га она прекорила зашто га сила сломи ирреко мора, али користи прилику да проговори и о његовом односу према њој:

Господару, Црнојевић Иво!

Ког' су љубе досле сјетовале,

Кога досле, кога ли ћ' одселе

С дугом косом, а памећу кратком.

(Вук II 1969: 378)

Ова изненадна опаска жене која није имала право гласа је дубоко разумевање психологије оног који је у сенци јачег. Зато јој Старац Милија дозвољава да каже свој став, да прекори господара на тренутак, али да не иде даље од тога. Овај ослобађајући моменат у свести жене јесте вербални излазак из сфере ћутања у којем је провела живот, као невеста Црнојевића. Ово је један од момената у певању Старца Милије који није доминантан и који не мора да утиче на ток радње, али је у психолошком и етичком смислу био битан за грађење вредносног система Старца Милије. Изводећи једну жену на епску позорницу у одлучном тренутку Старац Милија не само да јој даје могућност лаганог тријумфа, он јој даје и ореол највише етичке вредности изречене у стиховима:

Бога је велика гриота

А од људи зазор и срамота

Ђевојачку срећу затомити

И у њену роду узаптити.

(Вук II 1969: 197) 
Љуба Ива Црнојевића излази из свог устаљеног положаја, њено биће се буди и она казује своје мишљење и став, чиме из сфере пораженог, оног ко није вреднован,

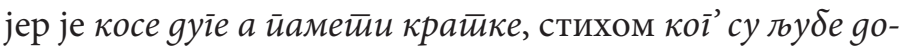
сле сјетиовале упућује тихи прекор свом господару.

Иако, како наводи Ненад Љубинковић „У Милијиним песмама жене нису добиле знатнији простор" (Љубинковић 2010: 466), приметићемо да Старац Милија женама даје значајно место. Оне имају улогу „да демаскирају мушкарце“ (Љубинковић 2010: 466). Оне су носиоци тихих победа које се исказују у кључним моментима када долази до драматичног тренутка преламања радње. Оно што је својствено Старцу Милији то је да брише границе ми/они. Не очекујемо од Латинке девојке, која у епској традицији има негативан предзнак и која је углавном само повод за сукоб, да изрази свој став. То ће се догодити само у фокусу певања Старца Милије, који је и у том свом поступку био изузетан и јединствен. Латинка девојка, због које је настао страшан сукоб у сватовима Црнојевића, на тренутак ће тријумфовати једном сасвим неочекиваном, а тако људском реченицом:

Ако су га красте нашарале, Здраве су му очи обадвије, Срце му је баш које је било.

(Вук II 1969: 393)

Ако успоставимо интертекстуалну везу са старишом дервишом из песме „Бановић Страхиња“ видећемо да се на истој линији етичке доминације налази и дервиш који, у турском табору, одговара Бановић Страхињи: 
И ако сам био у тамници,

Доста си ме вином напојио,

Бијелијем љебом наранио,

А често се сунца огријао.

(Вук II 1969: 201)

Стариша дервиш, у дијалогу са прерушеним Бановић Страхињом, поступно расте. Он подсећа Бановић Страхињу о пуштању на вересију, на откуп тамновања, уз давање тврде вере да ће да донесе благо и отплати тамновање. Старац Милија веома вешто доводи два јунака из супротног табора у исту раван. Бановић Страхиња остаје потпуно сам. Остављен од таста, Југовића, касније и сопствене љубе. Исту судбину доживеће и стариша дервиш. Он остаје без дома који је похаран, а старац Милија ће вештином сјајног певача успоставити лук између самоће Бановић Страхиње и похараног дервиша. Уз похараног Бановић Страхињу стајаће стих јуйрос Бану нема йријатиеља, а уз похараног Турчина,

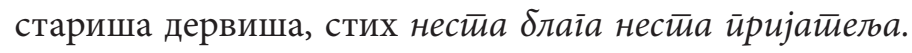
Турци у овој песми харају свога - Турчина. Суочен са похараним двором, као и Бановић Страхиња са својим, старац Милија прави лук између два јунака који имају исту судбину. Из сфере поражених он их вештином великог психолога доводи до тачке која значи поништавање националних оквира, и сусрета два Човека са различитих позиција. То је тачка у којој се поништавају све разлике и остаје само исијавање оне људске димензије у којој двојица поражених постају једно, сада у победи која се манифестује загрљајем, као највишом људском категоријом која уздиже етичке домете два људска бића. 
Виђе бане, познаде дервиша,

Од ђогата коња одсједаше

Пак загрли стариша дервиша:

Богом брате! Старишу дервишу!

На поклон ти моје дуговање.

(Вук II 1969: 201)

Овде уочавамо један значајан, наизглед безначајан моменат, а то је загрљај два човека, једног Србина и једног Турчина, уочи Косовске битке. Старац Милија, као човек дубоког разумевања трагичности појединца уочи свеопштих историјских потреса, за тренутак занемарује позицију колектива и борбу која предстоји. Он као да је, негде дубоко у себи, схватио сву трагику историјских дешавања у којима се не види лична судбина и лични усуд. Он је из тог разлога кретао у зараћене таборе и у њима тражио Човека. У томе је и успевао, разбијајући устаљене формуле, а да није изгубио ништа у естетском смислу. Напротив, створио је ликове који надилазе све што је до тада испевано. Људско разумевање два човека различите вероисповести подсећа на библијску причу и Самарићанину која говори о томе ко је човеку ближњи. Исус, после сликовите приче о пострадалом човеку коме помаже Самарићанин каже да је ближњи „онај који му милост учини“ (СП 2012: 80). Слично се догађа и у песми „Бановић Страхиња“. Српски јунак ражали се на тамновање Турчина и пушта га на вересију. И то уочи Косовске битке. Дервиш ће се одужити Бановић Страхињи тако што га неће проказати Турцима у намери да открије своїа gущманина.

Ове мале, а велике, победе старца Милије, нису уочљиве на прво читање. Он је, како наводи Владан Недић, сликајући Бановић Страхињу и стариша дервиша нагласио једну сродност „њихову страшну самоћу 
међу људима“ (Недић 1990: 90). Међутим, од песника „трагичне људске усамљености“ (Недић 1990: 90) Старац Милија постаје песник, могли бисмо рећи, победе усамљених јунака. Његови трагични јунаци, трагични у усамљености, баш из тог свог положаја постају неми победници. Прво, Бановић Страхиња није устукао пред зидом пред којим се нашао. Похарани муж и син, похарани зет не остаје на линији поражених. Остављен од свих он односи прву победу, а то је одлука да крене по отету љубу у турски табор, онако како није радио нико пре њега. Он управо из те своје трагичне усамљености доноси одлуку, највећу моралну одлуку да крене по отету љубу. Из стиха у којем Југ Богдан пада (Ал ако је јеgну ноћ ноћила) он расте и постаје нека врста соларног јунака што видимо у стиху Бан је озgо а сунащще озіо. Ова визуелна слика јесте врста небеске победе или вертикале која уздиже јунака до начела највише етичке вредности. Победе Бановић Страхиње су неме и то у минијатурним назнакама. Често се народни певач служи стиховима у којима ће бити назначене тихе победе осликане у покретима, као што је стих:

Погледује девет својих шура,

А шуреви у земљицу црну.

Бан погледну пашенога свога

Некакога млада Немањића

А Немањић гледа у земљицу.

(Вук II 1969: 197)

Занимљив је још један детаљ из супротног табора који није промакао старцу Милији. Колико год да је негативно сликао Влах Алију постоји један моменат, један стих који га је само на тренутак учинио другачијим од онога што он у песми јесте. То је моменат када љубу Бановић Страхиње низ Голеч планину јури хрт Караман: 
А Турчину очи испадоше,

Колико му нешто жао бјеше,

Те он гледа, што се чини шњоме.

(Вук II 1969: 207)

То је једини тренутак када Влах Алија, осликан као љути непријатељ који на најсуровији начин, отимањем жене, понижава свог противника, добија димензију мушкарца коме је жао жене која за једну ноћ постаје његова. Старац Милија је имао дубоки осећај за емпатију. Његово успоравање радње је у функцији сликања најдубљих осећања, са било које стране да долази. Љути Влах Алија који му је дворе похарао, мајку изгазио, а љубу одвео под свој чадор, у једном тренутку жали жену која је као свака жена, сйрашивица свака оg йашчаgи. Велики песник осликаће тај тренутак стиховима:

А Турчину очи испадоше

Колико му нешто жао бјеше,

Те он гледа, што се чини шњоме.

(Вук II 1969: 207)

И ништа више од тога. Само то, да би показао какав може да буде однос једног мушкарца према жени. Он на тренутак заборавља ко је Влах Алија, из потребе да се стави у позицију жене која је отета, за коју се боре два мушкарца и која, у страху за голи живот, помаже Турчину. Старац Милија заправо прави црно-белу слику свих актера догађаја. На неколико планова можемо да посматрамо пад једних и раст других јунака, односно пораз једних и у исто време победу других. Ако посматрамо два мушкарца који се боре око једне жене потребно је пажљиво погледати Бановић Страхињу и Влах Алију. У тренутку када љуба одлучује коме ће да 
помогне на равни етичке вертикале налазе се оштећени јунак (Бановић Страхиња) и отмичар (Влах Алија). И овде је старац Милија у нијансама категоризовао победника и губитника. У тренутку важном за исход песме, на Голеч планини, после страшне борбе gве але, одлука је на љуби Бановић Страхиње. Влах Алија у тренутку нуђења лепог живота пада још ниже јер је мами медом и шећером:

Душо моја, Страхињина љубо!

Немој мене, но удри Страхина, Нигда њему мила бити не ћеш, Пријекорна бити до вијека:

Кориће те јутром и вечером, Ђе си била са мном под чадором

Мене бити мила до вијека,

Одвешћу те Једренету граду,

Наредићу тридесет слушкињица,

Нек ти држе скуте и рукаве,

Ранићу те медом и шећером,

Окитити тебе дукатима

Саврх главе до зелене траве;

Удри саде Страхинића бана!

(Вук II 1969: 206)

Бановић Страхиња још једном односи победу, и као јунак и као мушкарац. Он јој даје могућност избора. Он не обећава ништа. Његова победа је у слободи избора коју даје својој љуби у тренутку када се одлучује исход његове жртве:

Удри, љубо, мене, ја Турчина:

Мисли, љубо, кога тебе драго.

(Вук II 1969: 206) 
Он само у два стиха даје љуби могућност да се определи. У овим стиховима види се сва величина победе пораженог. Он се уздиже величином јунака и мушкарца који добија атрибуте победника у тренутку када се одлучује о судбини и његовој и његове љубе. У овој реченици сублимирани су први и последњи стихови Нейко бјеше и йомало је йакијех јунака. Он показује својим поступцима витешки идентитет јунака који, како тумачи Никола Кољевић „Израста из нераскидиве осећајне везе са другим људима и животом у природи чији смисао он идеално заступа“ (Кољевић 1978: 168).

Старац Милија је кроз барометар својих вредности провукао пораженог који у ономе што говори постаје победник. Победа је и у оном тренутку када Бановић Страхиња љубу, која помаже Турчину, мирно ставља на коња и у себи побеђује оног другог јунака, који је све до овог Бановић Страхиње неверство кажњавао растрзањем коњима на репове, вађењем очију и спаљивањем. Ово је тренутак када се догађа нема победа самога себе. Управо је у томе највећа вредност старца Милије, што је умео пораженог да доведе до стања преокрета, духовног преокрета победе самога себе. Није ли на исти начин старац дервиш победио Турчина у себи и уместо оружја, које уочи Косовске битке чека да буде уперен на српски етнос, коме припада његов спасилац Бановић Страхиња, савезника нашао у алкохолу и самоћи. Они постају једини његови савезници и у свакодневном животу, и у важним биткама у које га не занимају.

На фону епског казивања старца Милије можемо да пратимо још један опозитан однос раста и пада јунака, односно опозитан однос победника и пораженог. У песми „Женидба Максима Црнојевића“ на истом фону пратимо Ива Црнојевића и Латинку девојку. Иво Црнојевић пада на самом почетку песме и заборавља 
табуе везане за етнопсихологију народа коме припада (Бандић 1991). Он заборавља на табу, односно забрану хваљења ближњег. Он на почетку песме хвали сина Максима приликом просидбе:

Неће бити љепшега јунака

У мојијех хиљаду сватова

Ни у твојих хиљаду Латина

Од Максима, од мојега сина

Сина мога, мила зета твога.

(Вук II 1969: 374)

„Крупне речи и велика обавеза“ (Џаџић 1995: 65), рекао би Петар Џаџић. У тренутку када Максима нагрде красте Иво Црнојевић види само спољашњост свога сина. Он пада као човек јер заборавља да је дужду од Млетака обећао да ће доћи за три године, а не долази. Али, у тренутку, када после борбе око невестинске кошуље долази до покоља међу сватовима, ореол победника у једном стиху добиће не неко од Црногораца, већ, неочекивано, Латинка девојка. Готово да нема епских песама у којима ће доћи до промене формуле да су Латини старе варалице. Старац Милија ће и у овој песми, у хтонским пределима које оличавају Латини, пронаћи онај стих и ону јунакињу која ће, као и Турчин, стариша дервиш, у једној епизоди песме „Бановић Страхиња“ постати победник по свом моралном поступку. Стихом Ако су їа крастие йойануле/Баш је срие као шйо је било Латинка девојка постаје на тренутак носилац етичког начела које није својствено епској формули. Милија одступа од формуле и издваја два своја лика, у две различите песме. Издваја два појединца из масе. Старца дервиша одваја од својих, Турака, који су већ на Косову, а Латинку девојку из сватова који би требало да 
буду носиоци највиших начела црногорске етнопсихолошке заједнице. Овде се све одвија другачије. Латинка односи људску победу. Она говори о Максиму Срие му

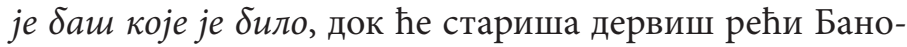
вић Страхињи gостиа си ме лебом наранио.

Ови моменти чине старца Милију необичним песником малих победа које су важне за налажење Човека у ситуацији када је све против човека. У галерији Милијиних ликова доминирају и исијавају они који се подижу са дна и, из наизглед већ унапред одређених пораза, постају победници, како би рекао Никола Кољевић, „митске универзалности“.

\section{Извори}

Српске народне пјесме, књига друга, Вук Стефановић Караџић, Београд: Просвета, 1969.

СП: Свето писмо старога и Новога завјета, Београд: Библијско друштво Србије, 2012.

\section{Литература}

Барић, Хенрих. Нет̄ко бјеше Сеирахинићу бане (Скица за методолошку студију). Београд: Српски књижевни гласник, 1936, н. С., XLIX.

Bakotić, Petar. Starac Milija, „Skolski vjesnik“, 1962, br. 1, str. 1325; br. 2, str. 1-23; br. 4, str. 1-11; br. 5-6, str. 23-31, br. 7. Str. 9-19; br. 8, str. 15-32.

Деретић, Јован. Истиорија срӣске къижевностии. Београд: Sezam Book, 2013.

Димитријевић, Иван. Заіонетика о Сӣрахинићу. Две студије о народној књижевности, Београд, 1930.

Кољевић, Никола. Иконобории и иконобранииеели. Београд: Нолит, 1978. 
Љубинковић, Ненад. Траїаға и оgі̄овори. Студије из народне књижевности и фолклора I, Београд: Институт за књижевност и уметност, 2010.

Маретић, Томо. Метирика нароgних наших ӣјесама II. Загреб: Рад ЈАЗУ, књ. 152, 1907.

Medenica, Radoslav. Banović Strahinja u krugu varijanata i tema o neveri žene u narodnoj epici. Beograd: Naučno delo, 1965.

Недић, Владан. Вукови иеевачи. Београд: Рад, 1990.

Поповић, Богдан. $O$ „йослеgним сиииховима“ иеесме „Бановић Сйрахиюа“. Прилози проучавању народне поезије, 1936, год. III, св. 1.

Сувајџић, Бошко. Јунаци и маске. Београд: Друштво за српски језик и књижевност, 2005.

Ћурчин, Милан. Срйска народна иесма у немачкој книжев-

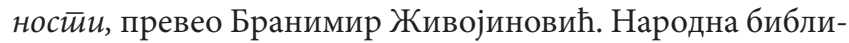
отека Србије - Народна библиотека „Вељко Влаховић“, Београд - Панчево 1987.

Цвијић, Јован. Говори и члании, I. Београд, 1921.

Чајкановић, Веселин. „Женидба Максима Црнојевића, српска народна песма с коментаром“ (В. Чајк). Бизерта,

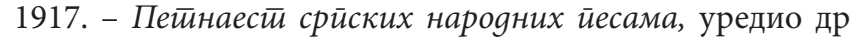
Веселин Чајкановић. Београд, 1925.

Џаџић, Петар. Homo balkanicus, homo heroicus. Београд: Завод за уџбенике и наставна средства, 1995. 
Valentina Pitulić

\section{THE WINNERS OF THE ELDER MILIJA}

The paper focuses on the characters of one of the best singers of Vuk Karadzic, Elder Milija. Elder Milija spoke to Vuk Stefanovic Karadzic through four songs that deviate from the usual formulas of epic singing. In this paper we shall demonstrate the way in which this gifted singer moved the boundaries of epic singing and deviated from formulas through which epic characters occurred. Special attention will be paid to the character of Strahinja Banovic, the dervish elder, the Latin girl and Ivo Crnojevic, because the actions of these characters best reflect the specific aspects of Elder Milija song-creation patterns, where the line between the winner and the defeated is very thin.

Key words: Elder Milija, the Winner, an Epic Hero, Ethics, Solitude, Defeat. 